\title{
CALLUS INDUCTION IN LEAF SEGMENTS OF Croton urucurana BAILL.
}

\author{
Indução de calos em segmentos foliares de sangra d’água (Croton urucurana Baill.)
}

\author{
Ednabel Caracas Lima ${ }^{1}$, Renato Paiva ${ }^{2}$, Raírys Cravo Nogueira ${ }^{3}$, \\ Fernanda Pereira Soares ${ }^{4}$, Eduardo Bucsam Emrich ${ }^{5}$, Álvaro Augusto Naves Silva ${ }^{6}$
}

\begin{abstract}
RESUMO
A sangra d'água, espécie pertencente à família Euphorbiaceae, apresenta potencial na recuperação de matas ciliares degradadas e é extensamente utilizada na medicina tradicional, como cicatrizante e no tratamento de reumatismos. Entretanto, suas sementes apresentam dormência e baixa viabilidade, dificultando a propagação desta espécie. Avaliou-se o efeito de diferentes concentrações de 2,4-D e BAP ou TDZ e de ANA e BAP, com suas possíveis combinações, na indução de calos em segmentos foliares de sangra d'água. Quarenta e cinco dias após a inoculação, foi avaliado o peso fresco dos calos. O uso de BAP isoladamente e a combinação entre ANA e BAP não promoveram calogênese em segmentos foliares de sangra d'água. Embora a combinação de 2,4-D e BAP ou TDZ tenha induzido a formação de calos, o uso isolado de 2,4-D proporcionou o maior peso fresco destes.
\end{abstract}

Termos para indexação: Micropropagação, calogênese, cultura de tecidos.

\section{ABSTRACT}

Croton urucurana Baill., a species belonging to the family Euphorbiaceae, can be useful in the recovery of degraded riparian areas. In the traditional medicine, it is widely used as cicatrizant and in the treatment of rheumatism. However, its seeds present dormancy and low viability, making the propagation of this species a challenge. With the objective of establishing an alternative route for the propagation, the effect of different concentrations of 2,4-D (2,4- dichlorophenoxyacetic acid) with BAP (6-benzylaminopurine) or TDZ (thidiazuron) and of NAA (1-naphthaleneacetic acid) with BAP and their possible combinations were evaluated for callus induction in leaf segments. Callus fresh mass was evaluated forty-five days after inoculation. The isolated use of BAP and the combination of NAA with BAP did not promote calogenesis in leaf segments. Even though the combination of 2,4-D with BAP or TDZ had induced the formation of callus, it was the isolated use of 2,4-D that provided the highest callus fresh mass.

Index terms: Micropropagation, calogenesis, tissue culture.

(Received in july 15, 2005 and approved in may 22, 2006)

\section{INTRODUCTION}

Croton urucurana Baill., a tree from Brazilian savanna, holds a great medicinal potential. It can be used in the treatment of rheumatisms and cancer as well as cicatrizant. From the restoration ecology point of view, it plays a very important role as it can be used to recover degraded areas.

This species is endemic to tropical and subtropical regions of South America. In Brazil, it occurs in the States of Bahia, Rio de Janeiro, Mato Grosso do Sul and Rio Grande do Sul, surpassing this country border and occurring also in Uruguay and Argentina (CORDEIRO, 1985).

Its fruits produce seeds in abundance, but shortly after the fruit dehiscence, coleopteras from the genus Apion
(Curculionidae; Apioninae) can be seen in the fruits, causing damage to the embryo and, therefore, drastically affecting the germination. Moreover, C. urucurana seeds present dormancy and low viability, being viable for no longer than four months (LORENZI, 2000).

The aspects above mentioned act as obstacles to the production of seedlings via sexual reproduction, which makes the tissue culture technique a viable alternative to overcome the problems that are inherent to the natural propagation of this species. Multiplication of $C$. urucurana can be achieved by micropropagation, either by organogenesis or somatic embryogenesis. In each case, by previously forming calli (GRATTAPAGLIA \& MACHADO, 1998).

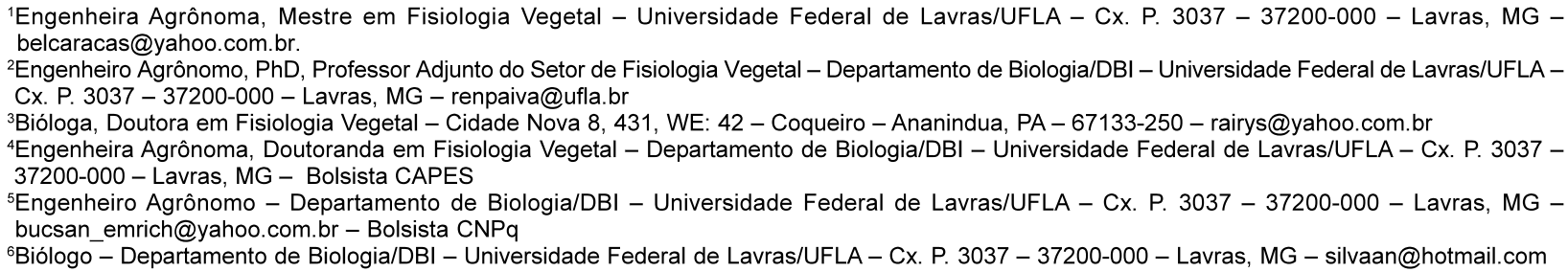


Calli are defined as tissues constituted by differentiated cells, which develop in response to a chemical or physical lesion, under determinate hormonal conditions (MANTELL et al., 1994). They can be obtained from a tissue fragment and have the ability to differentiate into tissues, organs and even embryos, being able to regenerate whole plants (PAIVA \& PAIVA, 2001; PIERIK, 1990; TORRES \& CALDAS, 1990).

The exogenous supply of growth regulators is frequently necessary in calogenesis (VIETEZ \& SAN-JOSÉ, 1996). This necessity refers to the type, concentration, relation auxin/cytokinin, genotype of the donor plant and the endogenous content of hormones.

According to George \& Sherrington (1984), the combination of auxins and cytokinins promote cellular differentiation and also organogenesis. Among the growth regulators used in callus induction, 2,4-D $(2,4-$ dichlorophenoxyacetic acid), NAA (1-naphthaleneacetic acid), BAP (6-benzylaminopurine) and TDZ (thidiazuron) are the most important.

The objective of this work was to assess the interaction of different concentrations of 2,4-D with TDZ or BAP and of NAA with BAP in the callus induction in leaf segments of $C$. urucurana.

\section{MATERIAL AND METHODS}

\section{Origin and disinfestation of plant material}

Source plants of $C$. urucurana about six months old were obtained from Centrais Elétricas de Minas Gerais (CEMIG) plant nursery, located at Represa de Camargos, in the county of Itutinga and were maintained in growth room at the Plant Physiology Sector of the Biology Department/Federal University of Lavras.

Young leaves collected from source plants were washed in running water and neutral detergent for 12 hours and then disinfested with $70 \%$ alcohol (v/v) for one minute in a laminar flux chamber followed by immersion in a $50 \%$ sodium hypochlorite solution (1\% active chlorine) for 15 minutes and rinsed five times in distilled autoclaved water. Disks of approximately $1 \mathrm{~cm}^{2}$ were excised from the leaves.

\section{Effect of the combinations of 2,4-D with TDZ or BAP}

The leaf explants were inoculated in WPM culture medium (LLOYD \& MCCOWN, 1980), supplemented with different concentrations of 2,4-D (0.0, 0.5, 1.0, 2.0, 3.0, 4.0 and $\left.5.0 \mathrm{mg} \mathrm{L}^{-1}\right)$ as well as TDZ $\left(0.0,0.5,1.0\right.$ and $\left.2.0 \mathrm{mg} \mathrm{L}^{-1}\right)$ or $\operatorname{BAP}\left(0.0,0.5,1.0\right.$ and $\left.2.0 \mathrm{mg} \mathrm{L}^{-1}\right)$, with their possible combinations and enriched with $30.0 \mathrm{~g} \mathrm{~L}^{-1}$ sucrose and 7.0 $\mathrm{g} \mathrm{L}^{-1}$ agar. The $\mathrm{pH}$ was adjusted to 5.8 and then autoclaved for 15 minutes at $121^{\circ} \mathrm{C}$.

After inoculation, the explants were kept in a growth room under irradiance of $36 \mu \mathrm{mol} \mathrm{m} \mathrm{m}^{-2} \mathrm{~s}^{-1}$, photoperiod of 16 hours and temperature of $27 \pm 2{ }^{\circ} \mathrm{C}$.

The explants were evaluated at 45 days after inoculation, using the callus fresh mass as the parameter. Treatments were arranged in a completely randomized block design with each treatment replicated 20 times. Each parcel was constituted by one tube, each one containing one explant per tube. The data were submitted to variance analysis and Tukey test was used at a $5 \%$ significance level to evaluate the results.

\section{Effect of the combinations of NAA with BAP}

The leaf explants were inoculated onto WPM culture medium supplemented with different concentrations of NAA $\left(0.0,1.0,2.0,3.0,4.0\right.$ and $\left.5.0 \mathrm{mg} \mathrm{L}^{-1}\right)$ as well as BAP $\left(0.0,1.0,2.0,3.0,4.0\right.$ and $\left.5.0 \mathrm{mg} \mathrm{L}^{-1}\right)$, with their possible combinations and enriched with $30.0 \mathrm{~g} \mathrm{~L}^{-1}$ sucrose and 7.0 $\mathrm{g} \mathrm{L}^{-1}$ agar. The $\mathrm{pH}$ was adjusted to 5.8 and then autoclaved for 15 minutes at $121^{\circ} \mathrm{C}$.

After inoculation, the explants were kept in a growth room under irradiance of $36 \mu \mathrm{mol} \mathrm{m} \mathrm{m}^{-2} \mathrm{~s}^{-1}$, photoperiod of 16 hours and temperature of $27 \pm 2{ }^{\circ} \mathrm{C}$.

The explants were evaluated at 45 days after inoculation, using the callus fresh mass as the parameter. Treatments were arranged in a completely randomized block design with each treatment replicated 20 times. Each parcel was constituted by one tube, each one containing one explant per tube. The data were submitted to variance analysis and Tukey test was used at a 5\% significance level to evaluate the results.

\section{RESULTS AND DISCUSSION}

The interaction of the auxin NAA with the cytokinin BAP in the concentrations tested was not effective to obtain calli in the leaf explants of $C$. urucurana. However, in the presence of 1.0, 2.0, 3.0, 4.0 and 5.0 $\mathrm{mg} \mathrm{L}^{-1} \mathrm{NAA}$ and in the absence of BAP, root emission was observed in the explants. This also happened when they were inoculated in the presence of 4.0 and $5.0 \mathrm{mg} \mathrm{L}^{-1} \mathrm{NAA}$ with $1.0 \mathrm{mg} \mathrm{L}^{-1}$ BAP.

Regarding the different combinations of 2,4-D with TDZ, the highest callus formation in the leaf explants of $C$. urucurana was observed with the isolated addition of 2,4$\mathrm{D}$ to the culture medium. There was no callus formation in the absence of this growth regulator.

TDZ was effective only in the calogenesis, when used in the concentration of $1.0 \mathrm{mg} \mathrm{L}^{-1}$, associated with 2,4-D, at the concentration of $0.5 \mathrm{mg} \mathrm{L}^{-1}$ (Figure 1). 
Table 1 shows that 2,4-D at the concentrations of 3.0 and $5.0 \mathrm{mg} \mathrm{L}^{-1}$ promoted the highest callus fresh matter, followed by the concentrations of 4.0 and $1.0 \mathrm{mg} \mathrm{L}^{-1}$. The lowest callus fresh matter was observed with the use of 2.0 $\mathrm{mg} \mathrm{L}^{-1} 2,4-\mathrm{D}$ and with the combination of $2.0 \mathrm{mg} \mathrm{L}^{-1} 2,4-\mathrm{D}+$ $0.5 \mathrm{mg} \mathrm{L}^{-1} \mathrm{TDZ}$.

Based on the fact that the concentrations of 2,4-D at 3.0 and $5.0 \mathrm{mg} \mathrm{L}^{-1}$ produced results that did not differ statistically from each other, we suggest the use of this growth regulator at $3.0 \mathrm{mg} \mathrm{L}^{-1}$ for callus induction in leaf segments of $C$. urucurana.

Concerning the effect of combination of 2,4D with BAP, it was observed that the concentrations of 2,4-D at 1.0, 2.0, 3.0, 4.0 and 5.0 $\mathrm{mg} \mathrm{L}^{-1}$ and the combination of $4.0 \mathrm{mg} \mathrm{L}^{-1} 2,4-\mathrm{D}$ with $2.0 \mathrm{mg} \mathrm{L}^{-1} \mathrm{BAP}$ promoted high weight variability, whereas the results from the other treatments remained at a similar level. Some combinations of
2,4-D with BAP did not present callus formation. Calogenesis was also absent in the control treatment as well as in the treatments containing only BAP (Figure 2).

Table 2 shows the average of the treatments where callus formation was present.

The auxin 2,4-D at the concentration of $4.0 \mathrm{mg} \mathrm{L}^{-1}$ and without the presence of BAP was the most effective in promoting callus induction, leading to the highest formation of fresh mass $(0.374 \mathrm{~g})$.

Similar results were achieved by Santos et al. (2005), who recommends 2,4-D at a concentration of $4.0 \mathrm{mg} \mathrm{L}^{-1}$ for the highest production of callus in Salix humboldtiana Willd.

On the other hand, Sahoo et al. (1997) observed that the concentrations of 2,4-D between 0.5 and $4.0 \mathrm{mg} \mathrm{L}^{-1}$ were not effective on inducing calogenesis in leaf explants of mulberry (Morus indica L.).

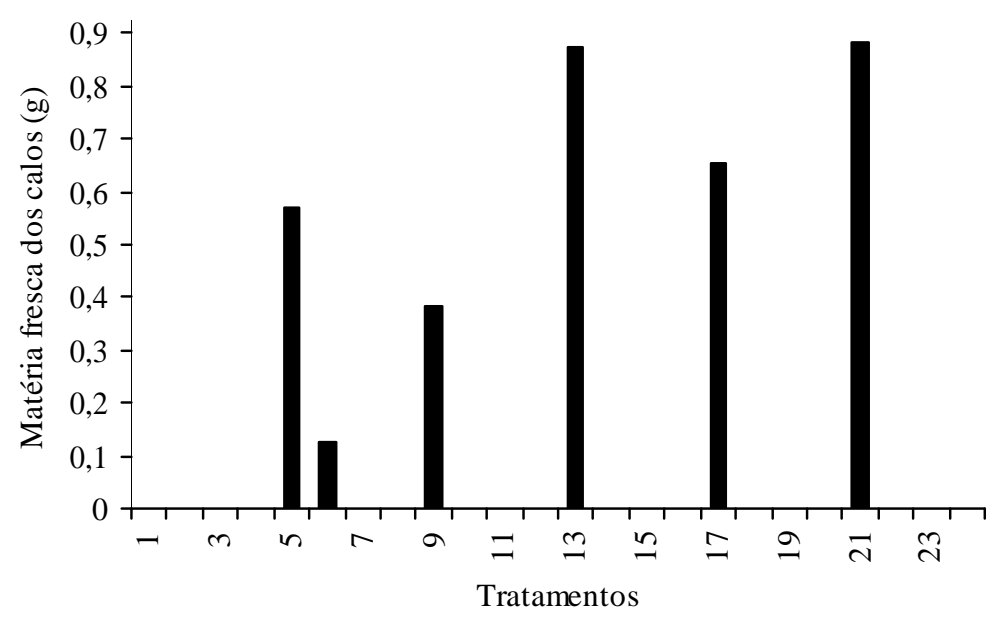

Figure 1 - Box-plot of callus fresh matter obtained from leaf segments of $C$. urucurana inoculated in WPM medium, supplemented with combinations of 2,4-D and TDZ.

Table 1 - Callus fresh matter obtained from leaf segments of $C$. urucurana inoculated in WPM medium, supplemented with 2,4-D and TDZ.

\begin{tabular}{lc}
\hline \multicolumn{1}{c}{ Treatments } & Average of callus fresh matter $(\mathrm{g})^{*}$ \\
\hline (T21) $5.0 \mathrm{mg} \mathrm{L}^{-1} 2,4-\mathrm{D}$ & $0.8815 \mathrm{a}$ \\
(T13) $3.0 \mathrm{mg} \mathrm{L}^{-1} 2,4-\mathrm{D}$ & $0.8756 \mathrm{a}$ \\
(T17) $4.0 \mathrm{mg} \mathrm{L}^{-1} 2,4-\mathrm{D}$ & $0.6537 \mathrm{~b}$ \\
(T5) $1.0 \mathrm{mg} \mathrm{L}^{-1} 2,4-\mathrm{D}$ & $0.5706 \mathrm{~b}$ \\
(T9) $2.0 \mathrm{mg} \mathrm{L}^{-1} 2,4-\mathrm{D}$ & $0.3833 \mathrm{c}$ \\
(T6) $1.0 \mathrm{mg} \mathrm{L}^{-1} 2,4-\mathrm{D}+0.5 \mathrm{mg} \mathrm{L} \mathrm{TDZ}$ & $0.1274 \mathrm{~d}$ \\
\hline
\end{tabular}

\footnotetext{
* Same letters in the column do not significantly differ at the $5 \%$ level of probability using Tukey test.
} 


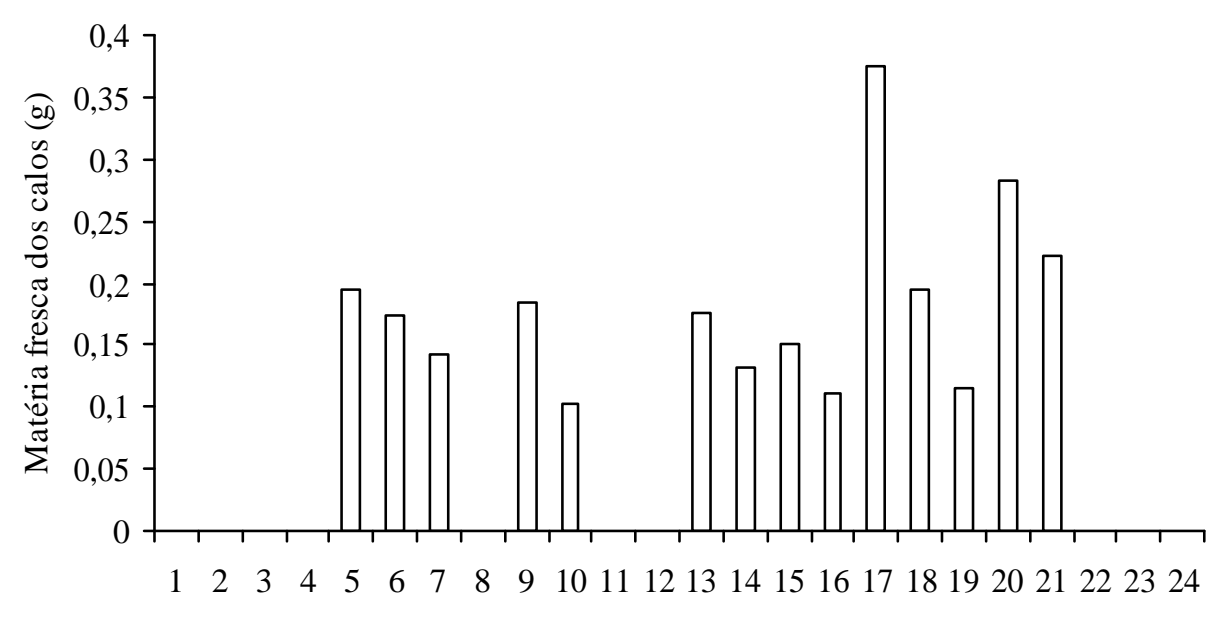

Tratamentos

Figure 2-Box-plot of callus fresh matter obtained from leaf segments of $C$. urucurana inoculated in WPM medium, supplemented with combinations of 2,4-D and BAP.

Table 2 - Callus fresh matter obtained from leaf segments of $C$. urucurana inoculated in WPM medium, supplemented with different combinations of 2,4-D with BAP.

\begin{tabular}{ll}
\hline Treatments & Callus fresh matter $(\mathrm{g})^{*}$ \\
\hline (T17) $4.0 \mathrm{mg} \mathrm{L}^{-1} 2,4-\mathrm{D}$ & $0.3740 \mathrm{a}$ \\
(T20) $4.0 \mathrm{mg} \mathrm{L}^{-1} 2,4-\mathrm{D}+2 \mathrm{mg} \mathrm{L} \mathrm{BAP}$ & $0.2825 \mathrm{~b}$ \\
(T21) $5.0 \mathrm{mg} \mathrm{L}^{-1} 2,4-\mathrm{D}$ & $0.2229 \mathrm{c}$ \\
(T5) $1.0 \mathrm{mg} \mathrm{L}^{-1} 2,4-\mathrm{D}$ & $0.1976 \mathrm{c}$ \\
(T18) $4.0 \mathrm{mg} \mathrm{L}^{-1} 2,4-\mathrm{D}+0.5 \mathrm{mg} \mathrm{L} \mathrm{BAP}$ & $0.1955 \mathrm{c}$ \\
(T9) $2.0 \mathrm{mg} \mathrm{L}^{-1} 2,4-\mathrm{D}$ & $0.1834 \mathrm{c}$ \\
(T13) $3.0 \mathrm{mg} \mathrm{L}^{-1} 2,4-\mathrm{D}$ & $0.1768 \mathrm{c}$ \\
(T6) $1.0 \mathrm{mg} \mathrm{L}^{-1} 2,4-\mathrm{D}+0.5 \mathrm{mg} \mathrm{L} \mathrm{BAP}$ & $0.1728 \mathrm{c}$ \\
(T5) $3.0 \mathrm{mg} \mathrm{L}^{-1} 2,4-\mathrm{D}+1 \mathrm{mg} \mathrm{L} \mathrm{BAP}$ & $0.1498 \mathrm{~d}$ \\
(T7) $1.0 \mathrm{mg} \mathrm{L}^{-1} 2,4-\mathrm{D}+1 \mathrm{mg} \mathrm{L} \mathrm{BAP}$ & $0.1416 \mathrm{~d}$ \\
(T14) $3.0 \mathrm{mg} \mathrm{L}^{-1} 2,4-\mathrm{D}+0.5 \mathrm{mg} \mathrm{L} \mathrm{BAP}$ & $0.1311 \mathrm{~d}$ \\
(T16) $3.0 \mathrm{mg} \mathrm{L}^{-1} 2,4-\mathrm{D}+2 \mathrm{mg} \mathrm{L} \mathrm{BAP}$ & $0.1123 \mathrm{~d}$ \\
(T19) $4.0 \mathrm{mg} \mathrm{L}^{-1} 2,4-\mathrm{D}+1 \mathrm{mg} \mathrm{L} \mathrm{BAP}$ & $0.1116 \mathrm{~d}$ \\
(T10) $2.0 \mathrm{mg} \mathrm{L}^{-1} 2,4-\mathrm{D}+0.5 \mathrm{mg} \mathrm{L} \mathrm{BAP}$ & $0.1017 \mathrm{e}$ \\
\hline
\end{tabular}

* Same letters in the column do not significantly differ at the $5 \%$ level of probability using Tukey test.

According to Grattapaglia \& Machado (1998), 2,4-D tends to stimulate callus formation, even at low concentrations. This growth regulator shows effect on the RNA metabolism by inducing the transcription of messenger RNA capable of coding proteins required for the growth and hence, promoting a chaotic cell proliferation, i.e., callus formation (GEORGE, 1996). 
Similar results to the ones found in this work with C. urucurana were also obtained in Inga vera Willd. The optimum concentration of 2,4-D was at $3.0 \mathrm{mg} \mathrm{L}^{-1}$, which induced the highest callus formation (80\%) (SOARES, 2003).

Regarding the combination of 2,4-D with TDZ, the results obtained here differ from those found by Deccetti (2000) in Annona glabra L. For this species an interaction between the growth regulators TDZ and 2,4-D was necessary for the maximum callus production.

In general, the results found in this work indicate that the combination of 2,4-D with BAP produces the lowest callus fresh mass in leaf explants of $C$. urucurana.

The results of this work support those found by other authors. For instance, Landa et al. (2000) did not observe callus formation in leaf explants of Caryocar brasiliense Camb. in the absence of 2,4-D while Vietez \& San-José (1996) did not obtain callus in leaf explants of Fagus silvatica L. in the presence of BAP.

Conversely, Santiago (2003) concluded that in leaf explants of Piper hispidinervum C. DC., the maximum callus production was achieved with the combination of $2,4 \mathrm{D}$ and BAP.

The results here indicate that exogenous supply of the auxin 2,4-D by itself was enough to promote a hormonal balance capable of inducing the highest callus formation in leaf tissues of $C$. urucurana.

\section{CONCLUSIONS}

The interaction of the auxins NAA and 2,4-D with the cytokinin BAP, in the tested concentrations, is not enough for callus production in leaf explants of $C$. urucurana.

The presence of 2,4-D is essential for callus induction in leaf explants of this species.

When used by itself in the culture medium, TDZ is not effective in inducing calogenesis in leaf explants of $C$. urucurana.

Maximum production of callus in leaf explants of C. urucurana is obtained when they are cultured on WPM medium, supplemented with $3.0,4.0$ or $5.0 \mathrm{mg} \mathrm{L}^{-1}$ 2,4-D.

\section{REFERENCES}

CORDEIRO, I. A família Euphorbiaceae na Serra do Cipó, MG, Brasil. 1985. 261 f. Dissertação (Mestrado) Universidade de São Paulo, São Paulo, 1985.

DECCETTI, S. F. C. Propagação in vitro de Annona glabra L. 2000. 101 p. Dissertação (Mestrado em Fisiologia Vegetal) - Universidade Federal de Lavras, Lavras, 2000.
GEORGE, E. F. Plant propagation by tissue culture: part 1: the technology. Edington: Exegetics, 1996. 574 p.

GEORGE, E. F.; SHERRINGTON, P. D. Plant propagations by tissue culture: handbook and directory of commercial laboratories. Grande-Bretane: Exegeties, 1984. 709 p.

GRATTAPAGLIA, D.; MACHADO, M. A. Micropropagação. In: TORRES, A. C.; CALDAS, L. S.; BUSO, J. A. Cultura de tecidos e transformação genética de plantas. Brasília, DF: Embrapa-SPI/Embrapa-CNPH, 1998. v. 1, p. 183-260.

LANDA, F. de S. L.; PAIVA, R.; PAIVA, P.D.O.; BUENO FILHO, J.S. Indução in vitro de calos em explantes foliares de pequizeiro (Caryocar brasiliense Camb.). Ciência e Agrotecnologia, v.24 (Edição Especial), p.5663, dez., 2000.

LLOYD, G.; MCCOWN, B. Commercially-feasible micropropagation of Mountain laurel, Kalmia latifolia, by use of shoot tip culture. International Plant Propagation Society Proceedings, Washington, v. 30, p. 421-427, 1980.

LORENZI, H. Árvores brasileiras: manual de identificação e cultivo de plantas arbóreas nativas do Brasil. 3. ed. Nova Odessa: Instituto Plantarum, 2000. v. 1, 386 p.

MANTELL, S. H.; MATTHEWS, J. A.; MCKEE, R. A. Princípios de biotecnologia em plantas: uma introdução à engenharia genética em plantas. Ribeirão Preto: SBG, 1994. $344 \mathrm{p}$.

PAIVA, R.; PAIVA, P. D. O. Textos acadêmicos: cultura de tecidos. Lavras: FAEPE/UFLA, 2001. 97 p.

PIERIK, R. L. M. Cultivo in vitro de las plantas superiores. São Paulo: M. Nijoff, 1990. 329 p.

SAHOO, Y.; PATTNAIK, S. K.; CHAND, P. K. Plant regeneration from callus cultures of Morus indica L. derived from seedlings and mature plants. Scientia Horticulturae, Amsterdam, v. 69, n. 1/2, p. 85-98, Mar. 1997.

SANTIAGO, E. J. A. de. Caracterização morfológica e bioquímica de calos de pimenta longa (Piper hispidinervium Candolle, De Candolle). 2003. 162 p. Tese (Doutorado em Agronomia/Fitotecnia) - Universidade Federal de Lavras, Lavras, 2003. 
SANTOS, B. R.; PAIVA, R.; MARTINOTTO, C.; NOGUEIRA, R.C.; PAIVA, P.D.O. Indução de calos friáveis em explantes foliares de Salix (Salix humboldtiana Wiild). Ciência Rural, v.35, n.3, p.510-514, mai-jun, 2005.

SOARES, G. de A. Aspectos do cultivo in vitro do ingazeiro [Inga vera Willd. subsp.affinis (DC) T. D. Penn]. 2003. 90 p. Dissertação (Mestrado em Fisiologia Vegetal) Universidade Federal de Lavras, Lavras, 2003.
TORRES, A. C.; CALDAS, L. S. Técnicas e aplicações da cultura de tecidos de plantas. Brasília, DF: Embrapa/CNPH, 1990. $433 \mathrm{p}$.

VIETEZ, A. M.; SAN JOSÉ, M. C. Adventitious shoot regeneration from Fagus sylvatica leaf explants in vitro. In vitro Cellular \& Developmental Biology, Largo, v. 32, n. 3, p. 140147, July/Sept. 1996. 